that the process never did any harm. These facts, in their bearing on asphyxia, are most valuable, as are also some others which illustrate that a living body may be submerged in water several minutes, and may yet recover after removal; but they have nothing directly to do with anæsthesia as a scientific study. Perfect anæsthesia is, in principle, the art of suspending sensation and sensibility without interfering with those processes on which the continuance of life depends. The administration of a gas which stops the process of respiration, though it suspends sensation and sensibility, for a short period prior to death, is no part of this perfected art; and we shall persist, notwithstanding Dr. Colton's practical knowledge, in upholding the principle of scientific investigation until the art is perfected.Ed. L.

\section{HEALTH OF NAPLES.}

\section{To the Editor of The Lancet.}

Sir,-When The LaNCET publishes as a fact that Naples is panic-stricken on account of the ravages of cholera, it is time to lay before the profession a few statistics which may enable them to form a judgment as to the severity of the epidemic. We will assume that the population of the city is half a million (in point of fact it is over). Between the 22nd August, 1873, and the 15th November, 1873, the number of deaths registered was 4176 , and during the same period (eighty-five days) in 1872,3191, showing an increased mortality during the prevalence of cholera of 985 . But of the 4176 deaths only 898 were due to cholera. Naples is not panic-stricken, and, as far as I can see, everything goes on as usual. The Times' correspondent, lately, in an article on the health of Rome, quotes certain statistics as to the number of deaths of English at Naples from October, 1872, to June, 1873. These statistics profess to be drawn from official sources. I do not see any allusion among the causes of death to gunshot wounds, nor to cutting and piercing wounds, and yet I have seen the bodies of three English subjects whose deaths were due to one or other of those classes of injuries. I have practised in Naples for three years, during the whole of which time I have lived in the Riviera di Chiaja, excepting a summer holiday at Sorrento, in Switzerland, and at Castellamare. With the exception of two of my children and another member of my family having had smart attacks of remittent fever, owing to imprudent exposure to the sun, followed by a chill from not being suffciently provided with warm wraps, and over-fatigue, and some attacks of an old enemy-rheumatism,-I may say that we have been perfectly healthy. Among bona fide English residents in the last few years there have been very few eases of typhoid. I have known several cases of remittent contracted in Naples or its immediate vicinity, but since the drainage of the Lago d'Agnano there is a marked improvement in this respect. I cannot see any good in attempting to show by figures that Rome, or any other city, is the healthiest in the world. The chief point to be looked at is the cause of illness amongst visitors. This is not difficult to discover. People now-a-days travel excessively, if I may be allowed the expression. They do their galleries, and churches, ruins, \&c., very conscientiously, but at too great a pace. Then follow a long and fatiguing railway journey, irregular meals, and a repetition of the hard labour of sightseeing. Your readers ean very easily imagine the effect of all this on, for example, a hard-working professional man, who wishes to make the most of his holiday, and see everything that there is of interest in the very least possible time. When nature at last rebels, and Nemesis, in the shape of a fever, seizes upon him, he does not for one moment imagine he is to blame, but immediately condemns the city in which be happens to be taken ill. Now Naples is generally the last visited of Italian cities, and so we get cases here of illness for which we get the credit. In point of fact, we could say that the disease was contracted elsewhere, but I think it fairer to attribute it to the imprudence of the patient. Long-continued fatigue, and unaccustomed exertion and excitement, irregular meals, and possibly unsuitable diet, must tell upon the nervous organisation, and open the door to disease. In the present epidemic it is worthy of remark that children and old people have suffered. It may be said that the lower orders only have suffered. They live on almost nothing, and have no power of resistance. In addition, their exceedingly nervous temperament has a great influence in any epidemic. As they believe that the Government employ doctors to poison them, and have besides no confidence in their medical men, they either refuse or do not seek relief. Much has been done in the matter of disinfecting, and much still remains to be done. Had Naples only a free supply of good water there would be a very marked change in the death-rate. Everyone is agreed on this point, but I am told that for eleven jears every municipality has thrown obstacles in the way of procuring it. If the correspondents of the English papers were to take this matter seriously in hand some good might be done. It is very useless to say one week that the Municipality are negotiating with Messrs. A.B. and C., and that there is every prospect of obtaining at length a supply of excellent water, and then a week or two afterwards regret to have to say that the prospect is as far off as ever, and that until Naples has its water-supply increased disease must prevail. I hope before long to be able to hand you statistics as to the causes of death in Naples, and in the meantime shall only say that in 1000 deaths 444.22 were children under five years. The sanitary bulletins show a decrease in the cholera, and the Syndic has ordered that municipal schools are to be reopened.

Readers of foreign newspapers should understand that an immense amount of political or religious feeling, and possibly of personal spite, is at the bottom of what they do not see a reason for; and also that an Italian adjective of the superlative degree is used to express what we might numerically express as one-fourth of a positive. Naples is by no means so black as it is painted, and those who, travelling easily, come here and live with common prudence, adopting a few simple precautions-such as non-exposure to the sun, especially when walking,-will find it an enjoyable and, if not a perfectly healthy residence, at least no worse in that respect than Rome, Florence, or many other cities or health-resorts where it is the fashion to cry down Naples.

Although sensation novel-writers send us all their scoundrels, I do not think it fair for professional journals to make us out worse than we are; and I therefore trust that you will allow space in your columns for this somewhat discursive apology for this beautiful city.

I am, Sir, yours faithfully,

Naples, Nov. 28th, 1873

J. A. Menzies, M.D. Edin.

\section{CAULIFLOWER EXCRESCENCE OF THE OS UTERI.}

To the Editor of THE LANCET.

Sin,-In your last report of the meeting of the MedicoChirurgical Society, I find a report of a paper on this disease by Dr. Snow Beck, in which he states that some cases I had reported in Guy's Hospital Reports were nothing but encephaloid disease. Of course it is merely a question of names. If Dr. Snow Beck prefers to limit the term "cauliflower" to simple villous disease, then what are we to eall the more cancroid forms which have a greater resemblance to a cauliflower than the simple villous disease? For myself I prefer to call the disease which is most like a cauliflower by that name. I do so because there is no hard and fast line between one and the other of the varieties. No one who has studied cancroids can so limit them. And this I have specially pointed out in the paper referred to. The growths were exactly like a "cauliflower," much more than to "brain." Hence I call them "cauliflower," and not "encephaloma." As I pointed out in my paper, there are various grades between simple villous disease and the least marked cauliflower disease, dependent on the relative in tensity of the malignant force and on the elementary tissue most affected byit.

I am, Sir, yours, \&c.,

$$
\text { J. BRAXTON HICKS, M.D., F.R.S. }
$$

George-street, Hanover-square, W. 